\title{
MANAGING COVID-19 THROUGH PREVENTIVE MEASURES
}

\author{
Gyanashree Kotoky \\ Teaching Associate, Department of Political Science, \\ Assam Women's University, Rowriah, Jorhat, Assam, India
}

\begin{abstract}
China tested its first COVID-19 positive in a patient on December 8, 2019. COVID-19 rapidly spread from a single city to the entire country in just 30 days. But only on February 11, 2020, the World Health Organisation announced an official name for the novel corona virus disease as coronavirus disease 2019 (COVID-19). The utter rapidity of both the geographical expansion and the sudden increase in the numbers of cases surprised and hurriedly stunned health and public health services in China. The source of the disease suggested of a common zoonotic spill over at Huanan Seafood Wholesale Market and another group doubts of a propagated source on seeing virus being to be transmitted only from person to person but its presence could not be seen among animals. As no medicine or vaccine could be made available in the market till date the only means to resist the rapid spread of the disease suggest for maintaining physical distancing and health hygiene. These methods of prevention reflected upon the words of Gandhi's on biomoralising of health and his emphasis on rural way of living. This article will travel back to analyse the relevance of 1940s' idealist model of Gandhi in present COVID-19 crises.
\end{abstract}

Key words: Gandhi, health-care, neo-liberalism, rural life, COVID-19, China

Cite this Article: Gyanashree Kotoky, Managing Covid -19 through Preventive Measures, International Journal of Management, 11(12), 2020, pp 1060-1064.

http://iaeme.com/Home/issue/IJM?Volume=11\&Issue=12

\section{INTRODUCTION}

The rapid spread of COVID-19 disease from Wuhan to the rest of the world within a short time of one month reawakened us of how small the world has become in this global age. Even islands like Andaman and Nicobar, surrounded by water, COVID-19 showed its presence. Besides questioning the geographical boundaries, the COVID-19 pandemic uncovered the hollowness and loopholes in the health sector and level of technological developments across countries. Keeping aside other countries, the First World countries like United States of America and England terribly failed in safeguarding its citizens or in providing medical health service to all even when public were ready to pay as much as needed. In A Letter from the Emergency Room, Dr. Rishi Goyal (Synapsis co-editor) reports that as of June 1, 2020 there 
were $6,057,853$ cases worldwide with 371,166 dead. He also states on the basis of a report by virologists testing upon random cases, about $5 \%$ of the tested population already possessed antibodies to the novel corona virus further fortifying the reality that the virus was circulating widely.

COVID-19 showed its first presence in China with the detection of corona virus in a body of Wuhan inhabitant and within a month, entire China was affected by it. As reported in Characteristics of and Important Lessons From the Coronavirus Disease 2019 (COVID-19) Outbreak in China by Zunyou Wu and Jennifer M. McGoogan, 87\% of the COVID-19 positive cases of China (till February 2020) were seen among patients of age group between $30-79$ years of age, $1 \%$ each among $0-9$ years and $10-19$, and $3 \%$ were affected from the age group of 80 years and above. Again $81 \%$ of the cases were mild, 14\% severe and 5\% critical. As reported in the article, the rapid spread of the virus was as a result of the crowd returning in buses, trains and buses to their family prior to China's annual Lunar New Year holiday. The Chinese government needed to act quickly as this meant each infected person could have numerous close contacts over a protracted time and across long distances. Understanding that as no specific treatment and prevention options or antiviral drugs and vaccines, were available for COVID-19, China focused on traditional public health outbreak response tacticsisolation, quarantine, social distancing, and community containment $(\mathrm{Wu}$ and McGoogan, 2020: 3-5). Of the cumulative 91, 181 COVID-19 cases, as on October 6, China has 398 active symptomatic cases and 375 active asymptomatic cases. The root ideology behind this is the Chinese's' consideration of personal and individual hygienty as a "national project of modernization in the twentieth-century" which is considered to reflect "state power, scientific standards of progress, the cleanliness of bodies, and the fitness of races". Here we find similarity with Gandhi's thought on health and hygiene as he considered that self-government starts from the body and only on conquering the enemies of the body Indians can think of serving the nation. It shows that Gandhi attributed healthy human body with national power (Alter, 1996). Here, with health he linked morality stating that only a person with morality can achieve a perfect health. The health tips that Gandhi offered required self-control over the diet and the environment of rural simple life amidst nature. This was against the human love for taste of tongue and the luxurious life which all aim for when one dreams of being efficacious.

\section{PUBLIC HEALTH: GANDHI'S APPROACH}

Corona virus infection commonly has the symptoms of fever and cough, loss of smell and taste and in severe cases lead to lower respiratory tract disease. To confirm the infection, it requires nucleic acid testing of respiratory tract sample but clinical diagnosis may be made based on symptoms, exposures, and chest imaging. As no specific effective antiviral therapies have been identified, supportive care for patients is typically the standard protocol.

In the context of China, the national security strategy for COVID-19 has shifted to a wartime control measures. Physical distancing and isolation were practiced by putting cities on lockdown which affected an estimated 760 million people. A range of technologically advanced and militarised approaches were used to keep inspection over its people and for identification of suspected cases. China also faced harsh criticism for silencing of dissenting voices who showed concern about the virus and put it up for the world media.

Other nations of the world practiced physical distancing and adopted sanitization measures following the footsteps of China. Without finding any medicine or vaccine for COVID-19, appropriate exposition to sunlight, using of warm water for the body, well ventilated space and going local seem the only way. These methods were vividly discussed by Gandhi in his writings on health to fight against any disease and more likely he focused on the 
preventative measures. In the context of Covid-19 too, preventive measures are emphasised upon by the top health organisation like World Health Organisation. Those with high immune level were less tested COVID-19 positive. And therefore, WHO during the very first few days of detecting the virus directed the nations to focus their citizens to have immunity building food and to do exercise. This is similar to Gandhi's approach to health. He wrote specifying the importance of exercise, walk, physical labour and sports for a healthy disease-free life. He forwarded the ashram style of rural living for freeing our bodies from any disease.

\section{NEO-LIBRALISM IN HEALTH SECTOR}

China on identifying patients with COVID-19 immediately isolated them in designated wards in existing hospitals. Along with this, 2 new hospitals in Wuhan and Huwai were rapidly built to isolate and care for the increasing numbers of cases. People coming in contact with COVID-19 cases were asked to quarantine themselves at home or were taken to special quarantine centers. Large public gathering functions, programmes and celebrations were cancelled. Restriction were imposed upon transportation and movement. These measures attributed in maintaining physical distancing. Besides these, in Wuhan and Hubei Province an estimated number of 40 million to 60 million residents were subjected to community containment measures. Though these types of traditional outbreak response actions have been successfully used in the past, they have never been executed on such a large scale. But there were also no other options.

In eighteenth-nineteenth century China weisheng (hygiene/sanitation) came to be the symbol of bifurcation between the civilized and the uncivilized. Middle-class consumers and intellectuals labelled themselves as sanitary and differentiated themselves from the unsanitary. The Japanese occupation of Tianjin after 1937 intensified hygienic modernity under colonial rule. In Tianjin, only the wealthy who could afford, were accessed to clean water and waste disposal system. However, the goals of weisheng in China reached its zenith with the achievement of a system of combined and collaborative effort comprising government institutions and individual participation to form the basis of a national health. Similarly, the neo-liberal ideology splits the population into those who are accountable, productive and independent and those who are dependent and need to rely on state welfare. Citizenship in this neoliberal context means to be autonomous and competent, interventions are thus geared towards changing individual behaviour to manage to take care of themselves and their children.

Under the neo-liberal influence, the Indian government's policy retort to prevailing inequality has been an increasing association with the rights regime, and supported by right based laws it is the responsibility of the individual to claim these rights. To some extent the ideology has been successful as it emphasises upon efficiency, accountability and equity. But neo-liberalism's believe upon lesser contribution from government and making individual more competent has limitation too. During the COVID-19 first wave, countries like USA severely faced its consequence with unpreparedness of the Government to face such large public health system breakdown. Every single frontline healthcare worker has been put in a condition of danger because of the politics of austerity and the "do more with less" ethos of neoliberal management philosophy. The scarcity of PPE was a result of ineffective planning. To face the shortage situation the internal class system of hospitals determined who was issued coveted N95 masks. The low-wage earning healthcare workers were left out to handle the cases and situation with simpler surgical masks.

Private equity, with its demand for steady profit margins, has been investing heavily in the health sector. EmCare and TeamHealth, the two largest United States emergency medicine staffing companies, were acquired by the private equity firms Onex and Blackstone Group, 
respectively. Together they manage almost 600 billion dollars in assets. Private equity typically extracts short term value out of a business, maximizing profit margins while increasing debt and finally selling at a gain. Emergency capacity and preparedness, by contrast, is seen as waste. As profits are prized over need, private equity organizations are plundering the public service of health care. The commodification of human health has placed the nations in a position of inadequate infrastructure. After strategic neglect, nursing homes, day care facilities and the like are understaffed, and the basic essential workers are underpaid. Preventive measures, better global public health care order for all, the development of improved hygiene habits, the expansion and synchronization of services and assistance for the disable, an increase in the living wage and better housing will all help in mitigating against the effect of this pandemic and future pandemics when vaccines or medicines are not applicable.

\section{CONCLUSION}

With the uncontrollable situation all across the world the WHO has called for more investment in surveillance and preparedness, but governments have been slow to take heed. A huge amount of funding has been committed for vaccine platforms but till date vaccines have not reached the market. Clinical trials of treatment are underway throughout the world, but a proper result and treatment method is still not into a process of universal acceptance. As mentioned in the editorial of Lancet, lecturing at the Munich Security Conference on Feb 15, 2020, WHO Director-General Dr Tedros Adhanom Ghebreyesus said, "we're not just fighting an epidemic; we're fighting an infodemic." The comfort through which inexactness and plots can be repeated and spread through social media and conventional outlets puts public health at a continuous disadvantage. It is the rapid broadcasting of trustworthy information - crystal clear identification of cases, data sharing, unrestricted communication, and peer-reviewed research - which is needed most during this period of uncertainty. There may be no way to prevent a COVID-19 pandemic in this globalised time, but verified information is the most effective prevention against the disease of panic along with the remedies of nature like cold and hot water treatment, sunlight, soil treatment over the body and living in well ventilated spaces.

\section{REFERENCES}

[1] Rogaski, Ruth (2004), Hygienic Modernity: Meanings of Health and Disease in Treaty-Port China. Berkeley and Los Angeles, California: University of California Press.

[2] Goyal, Rishi. A Letter from the Emergency Room. In Synapsis, 15 May, 2020

[3] Alter, Joseph S. (1996), Gandhi's Body, Gandhi's Truth: Nonviolence and the Biomoral Imperative of Public Health, The Journal of Asian Studies, 55(2), pp. 301-322.

[4] URL: http://www.jstor.org/stable/2943361. Accessed: 17/06/2014 07:05

[5] Wu, Zunyou and McGoogan (2020), Jennifer M. Characteristics of and Important Lessons From the Coronavirus Disease 2019 (COVID-19) Outbreak in China Summary of a Report of 72314 Cases From the Chinese Center for Disease Control and Prevention in Opinion. Jama, Febuary 24, 2020 Downloaded From: https://jamanetwork.com/ on 02/24/2020

[6] Editorial-COVID-19: fighting panic with information, The lancet, Vol 395, February 22, 2020

[7] Sidsel, Roalkvam (2014), Health governance in India: Citizenship as situated practice, Global Public Health: An International Journal for Research, Policy and Practice, 9:8, 910-926,

[8] DOI: 10.1080/17441692.2014.941900 http://dx.doi.org/10.1080/17441692.2014.941900 
[9] Alter, Joseph S. (2019), Nisargopchar Ashram: Gandhi's Legacy and Public Health in Contemporary India, Journal of the Anthropological Survey of India, 1-13

[10] Reprints and permissions: in.sagepub.com/journals-permissions-india

[11] DOI: 10.1177/2277436X19881260 journals.sagepub.com/home/ans

[12] Gandhi, Mohandas K. (1948), Key To Health, Ahmedabad: Navajivan Publishing House 